(Received May 21, 1984)

\title{
DISTRIBUTION OF SUBSTITUENTS IN CELLULOSE ETHERS PREPARED IN AQUEOUS AND NON-AQUEOUS SYSTEMS
}

\author{
By Akira Isogai, Atsushi Ishizu and Junzo Nakano \\ (Department of Forest Products, Faculty of Agriculture, \\ The University of Tokyo, Bunkyo-ku, Tokyo 113)
}

\section{Synopsis}

The distribution of substituents in partially substituted cellulose ethers (methyl-, carboxymethyl-, benzyl- and methallylcelluloses) prepared in aqueous and non-aqueous systems was studied. The reactivity order of three hydroxyl groups in cellulose in aqueous systems was $\mathrm{HO}-2>\mathrm{HO}-6>\mathrm{HO}-3$ with the exception for benzylation. On the other hand, the reactivity order was HO- $6>\mathrm{HO}-2 \simeq \mathrm{HO}-3$ for etherifications with powdered sodium hydroxide and etherifying reagents except iodides in a non-aqueous cellulose solvent, $\mathrm{SO}_{2}$-diethylamine-dimethylsulfoxide system. The difference in reactivities of the hydroxyl groups in the non-aqueous system were much smaller than those in aqueous systems.

\section{INTRODUCTION}

Cellulose ethers have been used in various fields and their properties are known to depend on degrees of substitution (DS), distribution of substituents, molecular weights and so on. Thus, the distribution of substituents in cellulose ethers have been one of important subjects in cellulose chemistry. Studies on the distribution of substituents in partially substituted cellulose ethers prepared from alkalicellulose (aqueous system) revealed that the relative rate-constant of $\mathrm{HO}-2$ was higher than that of HO-3 and the former was comparable to, and in some cases higher than, that of the primary hydroxyl group, $\mathrm{HO}-6^{1)-8}$, The higher reactivity of HO-2 than that of HO-3 observed for etherifications of both cellulose and its model compounds ${ }^{9)-14)}$ has been assumed to be due to the higher acidity of $\mathrm{HO}-2$ enhanced by its proximity of the anomeric center, $\mathrm{C}-1^{15}$. However, the reason for occasional observations of the higher reactivity of HO-2 than that of HO-6 has not been explained clearly yet ${ }^{15}$.

Recently, many kinds of non-aqueous cellulose solvents have been found ${ }^{16)}$, and these findings made it possible to prepare cellulose derivatives in cellulose solutions ${ }^{17)-19}$ ). The authors succeeded also in the preparation of many kinds of tri-O-substituted cellulose ethers by the use of a non-aqueous cellulose solvent $\left(\mathrm{SO}_{2}\right.$-diethylaminedimethylsulfoxide ${ }^{20) 211}$, and some chemical and physical characteristics of these new cellulose derivatives were reported ${ }^{22)}$.

In this work, the distribution of substituents in several kinds of partially substituted cellulose ethers prepared by the use of aqueous and nonaqueous systems was estimated by modern analytical techniques. The relative reactivities of three hydroxyl groups in anhydroglucose units of cellulose were discussed from a point of the effect of reaction media.

\section{EXPERIMENTAL}

\section{Materials}

Avicel (Asahi Chemical Ind. Co. Ltd., $\overline{\mathrm{DP}} \mathrm{v}=250$ ) was used as a cellulose sample. Commercial methylcellulose (Wako Chemical Ind. Co. Ltd., DS =1.6) and commercial carboxymethylcellulose sodium salt (Sunrose; Sanyo-Kokusaku Pulp Co. Ltd., DS $=1.4$ and 1.8) were used as samples of cellulose ethers prepared in aqueous alkalicellulose systems.

\section{Preparation of cellulose ethers}

Cellulose $/ \mathrm{SO}_{2}$-diethylamine (DEA)-dimethylsulfoxide (DMSO) solutions were prepared as described in the previous paper ${ }^{20) 21)}$. Methylcelluloses with various DS were prepared by adjusting the amounts of powdered sodium hy- 
droxide and dimethylsulfate or methyl iodide added to the cellulose solutions ${ }^{21)}$. The preparative conditions were shown in Table 1. MC were isolated by dialysis and subsequent lyophilization. Carboxymethylcellulose sodium salts (CMC) with various DS were prepared by reacting different amounts of powdered $\mathrm{NaOH}$ and sodium chloroacetate, bromoacetic acid or sodium iodoacetate with cellulose in its solution (Table 1). CMC were isolated by dialysis and subsequent lyophilization, and the DS of CMC were determined by the ${ }^{1}$ H-NMR method proposed by Ho et al. ${ }^{7)}$. Two kinds of benzylcellulose (BC) were prepared by the use of alkalicellulose and the non-aqueous cellulose solution as shown in Table 1. BC were isolated by pouring the reaction mixtures into methanol-water $(1: 1)$ and washing the precipitates with methanol and water repeatedly. Their DS were calculated from values of elementary analyses. Methallylcellulose (MAC) was prepared with powdered $\mathrm{NaOH}$ and methallyl chloride in the cellulose solution and isolated by the same method as used for BC. The DS of MAC was calculated from the content of double bonds measured by Wijs method ${ }^{23)}$.

\section{Analyses of distribution of substituents}

MC (50 mg) was dissolved in $15 \mathrm{ml}$ of $3 \%$ sulfuric acid and was hydrolyzed at $120^{\circ} \mathrm{C}$ for $1 \mathrm{~h}$. The hydrolyzates were neutralized with barium carbonate, and barium sulfate and excess barium carbonate were removed by centrifugations. The partially methylated glucoses thus obtained were subjected to reduction with sodium borohydride followed by acetylation with acetic anhydride ${ }^{24)}$. The partially methylated glucitol acetates were analysed by $\mathrm{GLC}^{18) 19}$.

The distribution of carboxymethyl groups in CMC was estimated by the method proposed by Ho and Klosiewicz").

BC was methylated twice by the Hakomori method. The fully methylated $\mathrm{BC}(60 \mathrm{mg})$ was dissolved in dichloromethane $(4 \mathrm{ml})$, and borontrifluoride etherate $(0.26 \mathrm{ml})$ and ethanethiol $(1.32$ ml) were added to the solution. The mixture was stirred vigorously at $20^{\circ} \mathrm{C}$ for $9 \mathrm{~h}$ to remove benzyl groups. Then, saturated sodium bicarbonate solution was added to the mixture for neutralization. After dichloromethane and ethanethiol were removed by evaporation, the partially methylated cellulose was isolated by dialysis and subsequent lyophilization. The distribution of methyl groups was analysed by GLC as described above.

MAC was methylated twice by the Hakomori method. The fully methylated MAC $(60 \mathrm{mg})$ and potassium tert-butoxide $(20 \mathrm{mg})$ were dissolved in anhydrous DMSO $(0.4 \mathrm{ml})$, and the mixture was heated at $100^{\circ} \mathrm{C}$ for $6 \mathrm{~h}$ to convert methallyl groups into 2,2-dimethylvinyl substituents. The permethylated 2,2-dimethylvinylcellulose was hydrolyzed successively with $90 \%$ formic acid at $100^{\circ} \mathrm{C}$ for $1 \mathrm{~h}$ and with $3 \%$ sulfuric acid at $120^{\circ} \mathrm{C}$ for $1 \mathrm{~h}$ to produce partially methylated glucoses. They were analysed as partially methylated glucitol acetates by GLC.

\section{RESULTS AND DISCUSSION}

\section{Preparation of cellulose ethers}

Table 1 shows DS and preparative conditions of cellulose ethers used in this work. The authors have already reported that the addition of sufficient amounts of powdered $\mathrm{NaOH}$ and etherifying reagents made it possible to prepare tri- $\mathrm{O}$-substituted cellulose ethers in the case of $\mathrm{MC}^{25}, \mathrm{BC}^{20}$ ) and $\mathrm{MAC}^{21)}$. In this work, partially substituted cellulose ethers were prepared by adjusting the amounts of powdered $\mathrm{NaOH}$ added. Cellulose ethers prepared from alkalicellulose are commercially available ones except BC-1, which was prepared by the method described in the previous paper $^{20)}$.

\section{Distribution of substituents in cellulose ethers}

\section{2-1. Methylcellulose}

Table 2 shows the results of GLC analyses of the substituent distribution $\left(X_{n}(n=2,3\right.$ and 6$\left.)\right)$ in MC, $X_{2}, X_{3}$ and $X_{6}$ were calculated from molar ratios of glucitol $\left(S_{0}\right)$ and its mono-, di-, triderivatives $\left(S_{2}-S_{236}\right)$ which were determined by GLC, and shown in the row of A. These values $\left(X_{n}\right)$ show the distribution of substituents as well as reactivities of hydroxyl groups. The DS represented as the sum of $X_{2}, X_{3}$ and $X_{6}$ coincide well with those shown in parenthesis in the same column, which were calculated from methoxyl contents. Molar ratios of partially methylated glucitols were calculated from $\mathrm{X}_{2}, \mathrm{X}_{3}$ and $\mathrm{X}_{6}$ with the assumption that the reactivity of each hydroxyl group was independent each other within the extents of DS shown in Table 2, and 
Table 1 DS and preparative conditions of cellulose ethers.

\begin{tabular}{|c|c|c|c|c|c|c|c|c|}
\hline \multicolumn{2}{|l|}{ Sample } & \multirow{2}{*}{$\begin{array}{l}\text { DS } \\
1.6\end{array}$} & \multirow{2}{*}{$\frac{\text { system }}{\mathrm{aq} \cdot{ }^{\mathrm{e})}}$} & \multicolumn{2}{|c|}{$\begin{array}{c}\mathrm{NaOH} \text { added } \\
(\mathrm{g} / \mathrm{g} \text { cellulose) }\end{array}$} & \multirow[t]{2}{*}{$\begin{array}{c}\text { Etherifying } \\
\text { reagent }\end{array}$} & \multicolumn{2}{|c|}{$\begin{array}{l}\text { Reaction conditions } \\
\left({ }^{\circ} \mathrm{C}, \mathrm{h}\right)\end{array}$} \\
\hline \multirow[t]{5}{*}{ commercial } & $\mathrm{MC}-1^{\text {a) }}$ & & & & - & & & - \\
\hline & $M C-2$ & 0.1 & non-aq. $\left.{ }^{f}\right)$ & & 4 & $\left(\mathrm{CH}_{3}\right)_{2} \mathrm{SO}_{4}$ & $60^{\circ} \mathrm{C}$ & $.3 \mathrm{~h}$ \\
\hline & $\mathrm{MC}-3$ & 1.0 & non-aq. & & 8 & $\left(\mathrm{CH}_{3}\right)_{2} \mathrm{SO}_{4}$ & $60^{\circ} \mathrm{C}$ & . $3 \mathrm{~h}$ \\
\hline & $M C-4$ & 0.4 & non-aq. & & 2 & $\mathrm{CH}_{3} \mathrm{I}$ & $20^{\circ} \rightarrow 60^{\circ} \mathrm{C}$ & $\cdot 3 h$ \\
\hline & $M C-5$ & 2.2 & non-aq. & & 4 & $\mathrm{CH}_{3} \mathrm{I}$ & $20^{\circ} \rightarrow 60^{\circ} \mathrm{C}$ & . $3 \mathrm{~h}$ \\
\hline commercial & CMC-1 & 1.4 & aq. + iso & PrOH & - & $\mathrm{ClCH}_{2} \mathrm{COOH}$ & & - \\
\hline \multirow[t]{9}{*}{ commercial. } & $C M C-2$ & 1.8 & $\mathrm{aq} \cdot+$ iso & ProH & - & $\mathrm{ClCH}_{2} \mathrm{COOH}$ & & - \\
\hline & CMC -3 & 1.2 & non-aq. & & 7 & $\mathrm{C}_{1 \mathrm{CH}_{2}} \mathrm{COONa}$ & $85^{\circ} \mathrm{C}$ & $.12 \mathrm{~h}$ \\
\hline & CMC -4 & 1.4 & non-aq. & & 8 & $\mathrm{ClCH}_{2} \mathrm{COONa}$ & $85^{\circ} \mathrm{C}$ & . $12 \mathrm{~h}$ \\
\hline & $C M C-5$ & 1.6 & non-aq. & & 9 & $\mathrm{ClCH}_{2} \mathrm{COONa}$ & $85^{\circ} \mathrm{C}$ & $\cdot 12 \mathrm{~h}$ \\
\hline & CMC -6 & 0.7 & non-aq. & & 18 & $\mathrm{BrCH}_{2} \mathrm{COOH}$ & $85^{\circ} \mathrm{C}$ & - $9 \mathrm{~h}$ \\
\hline & $C M C-7$ & 0.6 & non-aq. & & 9 & $\mathrm{ICH}_{2} \mathrm{COONa}$ & $20^{\circ} \rightarrow 60^{\circ} \mathrm{C}$ & . $3 \mathrm{~h}$ \\
\hline & $\left.B C-{ }^{C}\right)$ & 1.5 & aq. & & 6 & $\mathrm{C}_{6} \mathrm{H}_{5} \mathrm{CH}_{2} \mathrm{Cl}$ & $85^{\circ} \mathrm{C}$ & $\cdot 12 \mathrm{~h}$ \\
\hline & $\mathrm{BC}-2$ & 2.1 & non-aq. & & 4 & $\mathrm{C}_{6} \mathrm{H}_{5} \mathrm{CH}_{2} \mathrm{Cl}$ & $85^{\circ} \mathrm{C}$ & . $12 \mathrm{~h}$ \\
\hline & $\operatorname{MAC}^{\text {d) }}$ & 1.5 & non-aq. & & 6 & $\mathrm{ClCH}_{2} \mathrm{C}\left(\mathrm{CH}_{3}\right)=\mathrm{CH}_{2}$ & $70^{\circ} \mathrm{C}$ & $4 \mathrm{~h}$ \\
\hline
\end{tabular}

a) Methylcellulose. b) Carboxymethylcellulose sodium salt. c) Benzylcellulose. d) Methallylcellulose.

e) Aqueous alkalicellulose was used. f) $\mathrm{A} \mathrm{SO}_{2}$-DEA-DMSO system was used as a medium.

Table 2 Distribution of methyl groups in methylcelluloses.

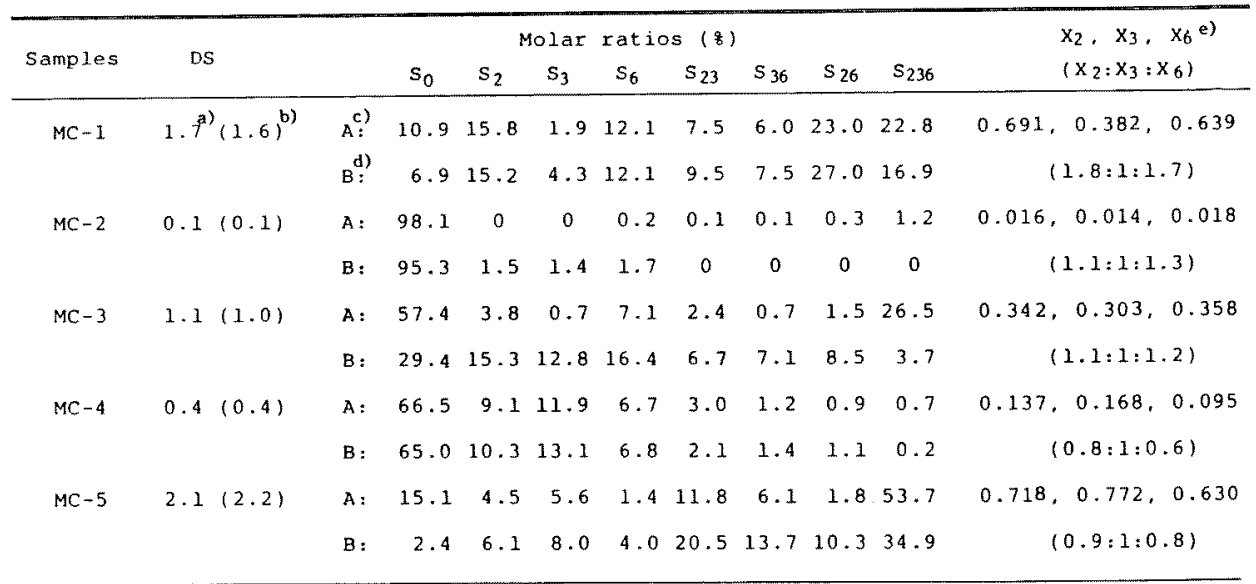

a) Calculated from yields of glucitol $\left(S_{0}\right)$ and its partially methylated derivatives $\left(S_{2} \sim S_{236}\right)$ determined by GLC, and for example $S_{2}$ means the molar ratio of 2-methylglucitol acetate.

b) Calculated from methoxyl content.

c) Data measured by GLC.

d) Data calculated from $X_{2}, X_{3}$ and $X_{6} ; S_{0}=\left(1-X_{2}\right)\left(1-X_{3}\right)\left(1-X_{6}\right) \times 100, S_{236}=X_{2} \cdot X_{3} \cdot X_{6} \times 100$, etc.

e) $X_{n}$ means a ratio of glucitol derivatives substituted at HO- $n(n=2,3$ or 6$)$. Ex, $X_{2}=\left(S_{2}+S_{23}+S_{26}+S_{236}\right) / 100$. 
these values were shown in the row of B in Table 2 . Thus, by comparing the values in the row of $\mathrm{A}$ with those in the row of $\mathrm{B}$, it can be deduced whether etherification reactions occurred homogeneously or heterogeneously for cellulose molecules, as discussed later.

As shown in Table 2, the relative reactivities of hydroxyl groups as estimated by $\mathrm{X}_{\mathrm{n}}$ were $\mathrm{HO}-2$ $\simeq$ HO- $6>\mathrm{HO}-3$ for the preparation of MC-1 from alkalicellulose (aq. system). This order of reactivities coincides with that reported for the same etherification by Croon and Lindberg ${ }^{1) 2)}$. In contrast, the relative reactivities for the preparation of MC-2 and MC-3 with powdered $\mathrm{NaOH}$ and dimethylsulfate in the non-aqueous solution were HO- $6 \simeq \mathrm{HO}-2 \simeq \mathrm{HO}-3$. In the case of methylation with methyl iodide (MC-4 and MC-5), the relative reactivities were $\mathrm{HO}-3 \approx \mathrm{HO}-2>\mathrm{HO}-6$ in contrast to those for the preparation of MC-2 and MC-3, and the differences in reactivities were small in these cases, too. In summary, the relative reactivities of hydroxyl groups found for the preparation of methylcellulose in the non-aqueous cellulose solution system (MC-2 $\sim$ MC-5) were quite different from that in an aqueous cellulose solution system (MC-1). Croon and Lindberg ${ }^{2)}$ reported that the order of the relative reactivities for methylation with dimethylsulfate in aqueous cellulose solutions was almost equal to that prepared from alkalicellulose. It should be noted as to their experiment, however, that water was present in both methylations. Therefore, the presence or absence of water may cause the differences in the relative reactivities of hydroxyl groups in the two methylation media.

As noted above, the relative reactivities of hydroxyl groups were different between methylations with dimethylsulfate and with methyl iodide. Joseleau et al. $^{26)}$ prepared methylcelluloses with methylsulfinyl anion and methyl iodide in DMSO (cellulose does not dissolve in this system) and in a cellulose solvent, $\mathrm{N}$-methylmorpholine $\mathrm{N}$-oxide, and reported that the relative reactivities were HO- $2 \simeq \mathrm{HO}-3 \simeq \mathrm{HO}-6$ in both systems. Brederek and $\mathrm{Dau}^{27)}$ methylated cellulose and cellulose triacetate with methyl iodide in the presence of sodium methoxide and benzyltetramethylammonium methoxide in a mixture of DMSO and benzene (non-aq.), and found that in both cases the relative reactivities of hydroxyl groups were $\mathrm{HO}-2>\mathrm{HO}-3$ $\simeq$ HO-6. These results together with the author's one (MC-4 and MC-5 in Table 2) indicate that the relative reactivities of hydroxyl groups towards etherifying reagents in non-aqueous systems become similar and the reactivity of HO-6 towards methyl iodide becomes the lowest. These effects found for the methylation with iodide are discussed in the latter section.

\section{2-2. Carboxymethylcellulose}

Table 3 shows the results of ${ }^{1} \mathrm{H}-\mathrm{NMR}$ analyses of various CMC. $\mathrm{X}_{2}, \mathrm{X}_{3}$ and $\mathrm{X}_{6}$ are determined directly from the NMR spectra and therefrom the first order relative rate constants $k_{2}, k_{3}$ and $k_{6}$ were calculated with the assumption that the reactivity of each hydroxyl group is independent each other. As shown in the Table, the relative reactivities of hydroxyl groups for the preparation of $\mathrm{CMC}-1$ and $\mathrm{CMC}-2$ from alkalicellulose were HO- $2>\mathrm{HO}-6>\mathrm{HO}-3$ in agreement with the recent reports ${ }^{7) 8}$. On the other hand, the relative reactivities were $\mathrm{HO}-6>\mathrm{HO}-2=\mathrm{HO}-3$ in the case of carboxymethylation with sodium chloroacetate and bromoacetic acid in non-aqueous cellulose solution systems (CMC-3 $\sim \mathrm{CMC}-6$ ). Interestingly, the use of sodium iodoacetate in the non-aqueous cellulose solution (CMC-7) brought about an increase of the reactivity of $\mathrm{HO}-3$. This effect is also found for the preparation of methylcellulose with $\mathrm{CH}_{3} \mathrm{I}$ in the non-aqueous systems (MC-4 and MC-5).

Reuben and Conner ${ }^{8)}$ reported that the relative rate constant $\left(k_{2}: k_{3}: k_{6}\right)$ showed the definite value up to the high DS (2.2). However, there are some differences among the ratios of $k_{2}: k_{3}: k_{6}$ in Table 3. Namely, the reactivities of hydroxyl groups are not found to be independent each other among the samples with various DS shown in Table 3.

\section{2-3. Benzylcellulose and methallylcellulose}

The distribution of substituents in partially benzylated and methallylated celluloses were analysed according to the schemes shown in Fig. 1. Although many kinds of catalytic hydrogenolysis have been reported for debenzylation reactions ${ }^{28)-31}$, they could not be applied successfully for debenzylation of benzylcellulose. Recently, Fuji et al. ${ }^{32}$ ) reported the combination use of borontrifluoride etherate and ethanethiol 
Table 3 Distribution of carboxymethyl groups in carboxymethylcelluloses.

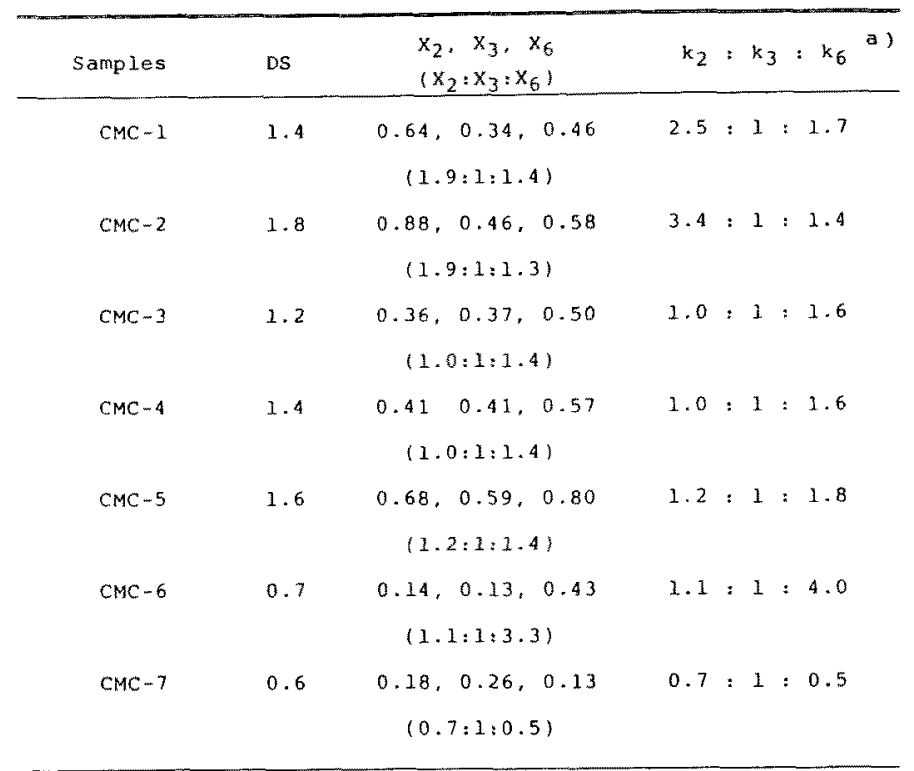

a) Relative rate constants of etherification at $\mathrm{HO}-2, \mathrm{HO}-3$ and $\mathrm{HO}-6$, calculated by the use of the following equations; $k_{2}: k_{3}: k_{6}=-\ln \left(1-X_{2}\right):-\ln \left(1-X_{3}\right):-\ln \left(1-X_{6}\right)$.

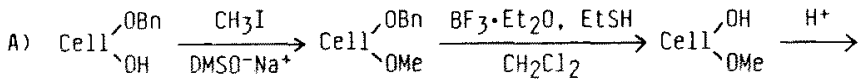

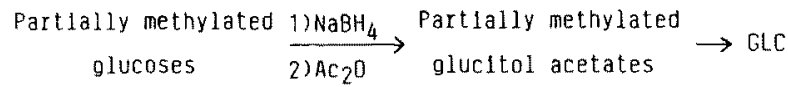

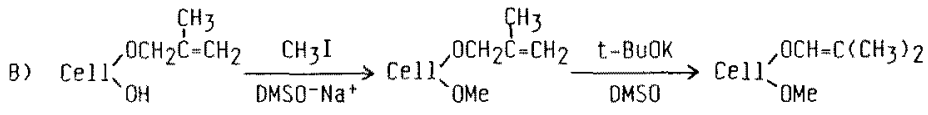
$\stackrel{\mathrm{H}^{*}}{\longrightarrow} \underset{\text { glucoses }}{\operatorname{Partlally} \text { methylated }} \frac{\text { 1) } \mathrm{NaBH}_{4}}{\text { 2) } \mathrm{Ac}_{2} \mathrm{O}} \rightarrow \mathrm{GLC}$

Fig. 1 Analytical schemes of benzylcellulose (A) and methallylcellulose (B).

for debenzylation. In our experiment, the procedure described in the experimental section were first applied to permethylated benzylcellulose, which was prepared from commercial methylcellulose by benzylation with powdered $\mathrm{NaOH}$ and benzyl chloride in its DMSO solution, and the benzylmethylcellulose thus prepared was proved to yield partially methylated glucitol acetates in the almost same ratios as original commercial methylcellulose.
The results are shown in Table 4. It is noticeable that in benzylation of alkalicellulose (BC-1), the reactivity of HO-6 is the highest, but the difference in the reactivities of hydroxyl groups is rather small. Furthermore, the order of the reactivities in the aqueous system was the same as that in the non-aqueous system. The steric effect of a benzyl group as compared with methyl and carboxymethyl groups may cause the highest reactivity of HO-6 even in the aqueous system on the analogy 
Table 4 Distribution of substituents in benzyl-and methallyl-celluloses.

\begin{tabular}{|c|c|c|c|c|c|c|c|c|c|c|c|}
\hline Samples & DS & & & Mo & lat 1 & ratios & $(8)$ & & & & $x_{2}, x_{3}, x_{6}$ \\
\hline & & & so & $S_{2}$ & $s_{3}$ & $S_{6}$ & $\mathrm{~s}_{23}$ & $s_{36}$ & 526 & $s_{236}$ & $\left(x_{2}: x_{3}: x_{6}\right)$ \\
\hline \multirow[t]{2}{*}{$\mathrm{BC}-1$} & $1.7^{\text {a) }}(1.5)^{\text {b) }}$ & $A:{ }^{C)}$ & 14.6 & 6.4 & 6.5 & 8.4 & 5.9 & 19.6 & 16.4 & 22.2 & $0.51,0.54,0.67$ \\
\hline & & $B:{ }^{d)}$ & 7.5 & 7.7 & 8.9 & 15.0 & 9.2 & 17.7 & 15.5 & 18.4 & $(0.9: 1: 1.2)$ \\
\hline \multirow[t]{2}{*}{$\mathrm{BC}-2$} & $2.1\{2.1\}$ & A: & 9.5 & 2.7 & 3.9 & 11.0 & 6.2 & 12.7 & 6.9 & 47.1 & $0.63,0.70,0.78$ \\
\hline & & B : & 2.5 & 4.2 & 5.8 & 8.8 & 9.8 & 20.2 & 14.7 & 34.2 & $(0.9: 1: 1.1)$ \\
\hline \multirow[t]{2}{*}{ MAC } & $1.4(1.5)$ & A: & 23.6 & 5.1 & 3.4 & 22.2 & 6.9 & 8.4 & 11.1 & 19.4 & $0.43,0.38,0.61$ \\
\hline & & B: & 13.8 & 10.2 & 8.5 & 21.7 & 6.3 & 13.4 & 16.1 & 9.9 & $(1.1: 1: 1.6)$ \\
\hline
\end{tabular}

a) See the footnote 1 in Table 2 .

b) Calculated from data of elementary analyses for $\mathrm{BC}$ or the content of double bonds for MAC.

c) and d) See the footnote 3 and 4 in Table 2 , respectively.

of triphenylmethylation and diphenylmethylation.

For allylation of alkalicellulose with sodium allylsulfonate in an aqueous system ${ }^{3)}$, the relative reactivities were reported to be $\mathrm{HO}-6>\mathrm{HO}-2$ $>$ HO-3. As shown in Table 4 , the relative reactivities were $\mathrm{HO}-6>\mathrm{HO}-2 \simeq \mathrm{HO}-3$ for methallylation in the non-aqueous system.

3. Effect of reaction media on homogeneity of etherifications for cellulose molecules, and on reactivities of hydroxyl groups in cellulose

\section{3-1. Homogeneity of etherifications for cellulose molecules}

According to Yamazaki and $\mathrm{NakaO}^{33)}$, cellulose dissolves in a $\mathrm{SO}_{2}$-DEA-DMSO mixture by forming a complex among a hydroxyl group in cellulose, a $\mathrm{SO}_{2}$ molecule and a DEA molecule. This complex may be destroyed by addition of powdered $\mathrm{NaOH}$ to yield non-crystalline sodium cellulosates. This expectation could be supported by our success in the facile preparation of tri-O-alkylcelluloses by the use of a cellulose solvent together with powdered $\mathrm{NaOH}$ and alkyl iodides ${ }^{22}$ 25), because alkylations were known to occur at Cell- $\mathrm{O}^{-}$with atkyl iodides (ex. $\mathrm{CH}_{3} \mathrm{I}$ ) by $\mathrm{S}_{\mathrm{N}} 2$ in non-aqueous media ${ }^{34}$ ),

As shown in Table 2, the molar ratios of partially methylated glucose residues (A) measured for MC-1 coincide well with those (B) calculated from the values of $\mathrm{X}_{2}: \mathrm{X}_{3}: \mathrm{X}_{6}$, indicating that this methylation in alkalicellulose system (aqueous) occurs homogeneously for whole cellulose molecules according to the probability. On the other hand, the molar ratios (A) measured for MC-2 MC-5 were different from the calculated ones (B), and the permethylated glucose residue $\left(\mathrm{S}_{236}\right)$ and the unmethylated residue $\left(S_{0}\right)$ had relatively large ratios for all these samples. Namely, these results show that these methylations occur heterogeneously for cellulose molecules contrary to our expectation when the non-aqueous cellulose solvent was used. Possibly this heterogeneity for methylations may be explained as follows: amorphous sodium cellulosate formed by addition of powdered $\mathrm{NaOH}$ into a cellulose/ $\mathrm{SO}_{2}$-DEA-DMSO mixture are so reactive in non-aqueous systems that methylation may proceed immediately at the reaction site.

Also the benzylation of aqueous alkalicellulose was found to proceed more homogeneously than that in the non-aqueous cellulose solution (Table 4).

\section{3-2. Reactivities of hydroxyl groups in non- aqueous system}

Studies on the distribution of substituents in partially substituted cellulose ethers prepared in the non-aqueous system revealed that reactivities of hydroxyl groups were generally $\mathrm{HO}-6>\mathrm{HO}-2$ $\simeq \mathrm{HO}-3$, and that the differences in reactivities of hydroxyl groups are much smaller than those in the aqueous systems. The highest reactivity of HO-6 may be due to sterical preference to etherifications, and the acidity of HO- 3 was almost equal to that of $\mathrm{HO}-2$ in the non-aqueous cellulose solution system.

\section{3-3. Reactivities of hydroxyl groups in aqueous systems}

Studies on the distribution of substituents in $\mathrm{MC}$ and $\mathrm{CMC}$ prepared from alkalicellulose revealed that the reactivities were $\mathrm{HO}-2>\mathrm{HO}-6>\mathrm{HO}-3$, being identical with results of other researchers. 
The highest reactivity of $\mathrm{HO}-2$ and the lowest one of HO-3 have been explained to be due to the supposed difference in their acidities. That is, the acidity of $\mathrm{HO}-2$ has been assumed to be higher because of its proximity to the anomeric center ${ }^{15}$. However, if such an explanation is true, the difference among reactivity of HO-2 and HO-3 would be much higher in the non-aqueous system, too. In addition to acidities, therefore, factors such as electrostatic, steric, solvating, hydrogen bonding and other effects may be expected to cause the difference among reactivities of hydroxyl groups in aqueous system.

\section{CONCLUSION}

Etherifications of cellulose in aqueous (heterogeneous) and non-aqueous (homogeneous) systems showed different characteristics as follows:

1) Etherifications in the aqueous systems proceed more homogeneously than those in the nonaqueous system.

2) The reactivity orders of three hydroxyl groups in cellulose generally are $\mathrm{HO}-2>\mathrm{HO}-6>\mathrm{HO}-3$ in the aqueous systems and $\mathrm{HO}-6>\mathrm{HO}-2=$ $\mathrm{HO}-3$ in the non-aqueous system.

3) The differences among the reactivities of hydroxyl groups in the non-aqueous system are much smaller than those in the aqueous systems.

\section{REFERENCES}

1) I. Croon and B. Lindberg, Svensk Papperstidn., 61, 963 (1958).

2) I. Croon and B. Lindberg, ibid., 60, 843 (1957).

3) D. E. Hoiness, C. P. Wade and S. P. Rowland, Can. J. Chem., 46, 667 (1968).

4) O. Ramnas, Acta Chem. Scand., 27, 3139 (1973).

5) E. J. Roberts and S. P. Rowland, Can. $J$. Chem. 45, 261 (1967).

6) E. J. Roberts and S. P. Rowland, ibid., 47, 1581 (1969).

7) F. F.-L. Ho and D. W. Klosiewicz, Anal. Chem. 52, $913(1980)$.

8) J. Reuben and H. T. Conner, Carbohydr. Res., 115, 1 (1983).
9) H. M. Spurlin, J. Am. Chem. Soc., 61, 222 (1939).

10) E. Avela and B. Holmbom, Acta Acad. Abo. Ser. B, 31, p14 (1971).

11) A. N. Belder, B. Lindberg and O. Theander, Acta Chem. Scand., 16, 2005 (1962).

12) A. M. Bills and J. W. Green, J. Chem. Soc., B 716 (1967).

13) Yu. S. Ovodov and E. V. Evtuskenko, Carbohydr. Res., 27, 169 (1973).

14) S. Sato, Y. Takabe and S. Zen, Bull. Chem. Soc. Jap., 45, 291 (1972).

15) A. H. Haines, Advan. Carbohydr. Chem., 33, 11 (1976).

16) S. M. Hudson and J. A. Cuculo, J. Makromol. Sci-Rev., Makromol. Chem., C18, 1 (1980).

17) T. Ishii, A. Ishizu and J. Nakano, Carbohydr. Res., 59, 155 (1977).

18) A. Isogai, A. Ishizu and J. Nakano, Sen-i Gakkaishi, 37, T363 (1981).

19) A. Isogai, A. Ishizu and J. Nakano, Cellulose Chem. Technol., 17, 123 (1983).

20) A. Isogai, A. Ishizu and J. Nakano, J. Appl. Polym. Sci. 29, 2097 (1984).

21) A. Isogai, A. Ishizu and J. Nakano, ibid., in press.

22) A. Isogai, A. Ishizu and J. Nakano, ibid., in press.

23) J. A. Wijs, Chem. Ber., 31, 750 (1898).

24) P. Albersheim, D. J. Nevis, P. D. English and A. Karr, Carbohydr. Res., 5, 340 (1967).

25) A. Isogai, A. Ishizu, S. Eda, K. Katō and J. Nakano, ibid., in press.

26) J.P. Joseleau, G. Chambat and B. C.Hermoza, ibid., 90, 339 (1981).

27) K. Brederek and T. B. P. Dau, Angew. Makromol. Chem., 89, 167 (1980).

28) C. H. Heathcock and Y. Ratcliffe, J.Am. Chem. Soc., 93, 1746 (1971).

29) J. S. Bibdra and A. Grodski, J. Org. Chem., 43, 3240 (1978).

30) G.M. Anantharamaiah and K.M. Sivanandaiah, J. Chem. Soc, Perkin Trans., 1, 490 (1977).

31) A. M. Felix, E. P. Heimer, T. J. Lambros, C. Tzougraki and J. Meienhofer, J. Org. Chem.. 43, 4194 (1978).

32) K. Fuji, K. Ichikawa, M. Noda and E. Fujita, ibid., 44, 1661 (1979).

33) S. Yamazaki and T. Nakao, Sen-i Gakkaishi, 30, T234 (1974).

34) I. Ciucanu and F. Kerek, Carbohydr. Res., $131,209(1984)$. 
水系および非水系で調製したセルロース

\title{
エーテル類の置換基分布
}

\begin{abstract}
東京大学農学部磯貝 明, 石津 敦, 中野準三
非水系セルロース溶剤の一種である， $\mathrm{SO}_{2}$-ジエチル アミンージメチルスルホキシドを用い，粉本苛性ソーダ とエーテル化剤により合成したセルロースエーテル類（メ チルー，力ルボキシメチルー，ベンジルー，メタリルー セルロース）の置換基分布在測定し，アルカリセルロー

アルカリ七ルロースのエーテル化における各水酸基の反 㤁性が $\mathrm{HO}-2>\mathrm{HO}-6>\mathrm{HO}-3$ であったのに刘して，非 水采セルロース溶剂を用いた場合にはHO-6>HO-2 HO-3となり，さらに各水酸基の反応性の差は水系の場 合に比べて小さいととが見出された。
\end{abstract} スから合成したセルロースエーテル類のそれと比較した。 